\title{
A study on health and sanitation practices among women residing in slum area of Lucknow district
}

\section{Shivani Srivastava}

Author for Correspondence

Shivani Srivastava

N.S.C.B. Govt. Girls P.G.

College, Aliganj, Lucknow (U.P.) India

Email : shivanisrivastava1964@

yahoo.com

Received: 27.02.2020; Revised: 01.04.2020; Accepted: 17.05.2020

ABSTRACT : Woman's are the venerable group of our society still women's living in some area such as slum are not treated same due to their residence. The woman's residing in the Slum area leading their lives in an unfeasible manner. These unfeasible manner is directly associated with their health and sanitation practices. Health and sanitation are the important aspects of our lives and the practices followed are the indicators of the leading the future diseases. The present study was an attempt to study the health and sanitation practices adopted by the woman's living various slum area of Lucknow district. The sample of total 250 woman selected randomly from different slum area of the Lucknow district. The data was collected by interview method using self structured interview schedule. The study revealed that majority (98\%) of woman were married. More than 50 per cent were lived in katcha houses where as 64 per cent had no proper water supply. About 58 per cent woman's were illiterate and 46 per cent were housewives.76.4 per cent were going public health centres for any health related issues and 51.2 were usually suffering from cough and cold. 52 per cent were aware about the health services and same were benefitted from those services. 88 per cent were eating stale foods. 92 per cent women were not using sanitary pads during menstruation. Due to poor menstrual hygiene they are prone to some infectious and most serious health risks such as urinary tract diseases and sexually transmitted diseases. The study conclude that more than half of the women's still have lack of information about health services and for better sanitation practices there is still need to provide more knowledge and awareness among them so that they can easily take it in practice.

KEY WORDS: Katcha houses, Slum area, Women, Health, Sanitation

- HOW TO CITE THIS PAPER : Srivastava, Shivani (2020). A study on health and sanitation practices among women residing in slum area of Lucknow district. Asian J. Home Sci., 15 (1) : 143-148, DOI: 10.15740/HAS/AJHS/15.1/143-148. Copyright@ 2020: Hind Agri-Horticultural Society. 